\title{
Study on Revitalization of a Small-Scale Biodiesel Plant with 6 tpd Capacity in Kotabaru, South Kalimantan
}

\author{
Khairil Amria*, Imam Paryantoa, Maharani Dewi Solikhah ${ }^{a}$ and Romelana \\ ${ }^{a}$ Centerfor Engineering Design and Technology System, Agency for the Assessment and Application of Technology (BPPT), \\ Gedung 480 Kawasan PUSPIPTEK Serpong, Tangerang Selatan 15314, Banten, Indonesia
}

\begin{abstract}
The aim of this study was to find a solution on revitalization of the biodiesel plant of 6 tons/day capacity in Serongga, Klumpang Hilir Sub-district, Kotabaru District at Province of South Kalimantan that managed by the Local Government of Kotabaru. Based on the surveys, the biodiesel plant has not worked properly for 3 years since the last commissioning. The reasons for the biodiesel plant not operating were caused by technical, management and economic problems. This paper studied the technical problem, calculation of the estimation cost for repair, replacement and installation of equipments and instruments, analysis of Strength, Weakness, Opportunity and Treat (SWOT), and analysis of economic feasibility in the operation of biodiesel plant. Based on the SWOT Analysis, it was found that the operation of biodiesel plant was strongly influenced by the security of supply and price of raw material, local government efforts to penetrate the market, and increased added-value of by-product. To increase the economic value of the plant in the future, a review on the economic and sensitivity analysis of several options was conducted. The available solutions were to revitalize the plant and operate the plant at the existing location (Scenario 0), to integrate biodiesel plant into a nearby palm oil mill (Scenario 1) and to move the plant at the mining site (Scenario 2). Economic calculation analysis results that integrating biodiesel plant with palm oil mill nearby was the best option (Scenario 1). Based on sensitivity analysis of Scenario 1, financial margin was strongly influenced by the CPO, methanol and biodiesel prices
\end{abstract}

Keywords: Biodiesel Plant, Revitalization, SWOT, Economic Analysis, Integration

\section{Introduction}

Biodiesel, which is defined as the mono-alkyl esters of long chain fatty acids derived from a renewable lipid feedstock, has received considerable attention worldwide as a medium-term alternative to diesel fuel obtained from petroleum. Biodiesel can be produced by trans-esterification of oils with short-chain alcohols, such as methanol, or by esterification of free fatty acids (FFA). The trans-esterification reaction was take place in the presence of a suitable catalyst such as alkali or acid and glycerol is the only byproduct produced. Approximately $100 \mathrm{~kg}$ of oil reacts with $10 \mathrm{~kg}$ of methanol to produce $100 \mathrm{~kg}$ of biodiesel and $10 \mathrm{~kg}$ of glycerol. Biodiesel could also be produced at supercritical conditions in the absence of any catalyst or through biochemical routes based on the use of enzymes (Briggs, 2008).
Biodiesel can be produced from any material that contains fatty acids, whether linked to other molecules or present as free fatty acids. Thus various vegetable fats and oils, animal fats, waste greases, and edible oil processing wastes can be used as feedstock for biodiesel production. The choice of feedstock is based on such variables as local availability, cost, government support and performance as a fuel (Haas et al, 2005).

Indonesia as the biggest producer of palm oil in the world had enough resources to produce biodiesel in large scale. But the large abundant of palm oil production was not linier with the production of biodiesel. Based on APROBI (Indonesian Bio-fuel Producer Association, in Indonesian) data, within the total installed biodiesel plant capacity in Indonesia of 4.28 million Kiloliters, less than $50 \%$ of total capacity operates and produces biodiesel. Beside the technical factors, there were several nontechnical limiting factors that slowing the development of biodiesel such as

\footnotetext{
"Corresponding author : Tel : +62-21-7563213

Email : khairil.amri@bppt.go.id
} 
feedstock price, biodiesel production cost, biodiesel price and taxation (Tjakrawan 2012).

The government has issued several policies to accelerate the utilization of biodiesel fuel in Indonesia such as Presidential Regulation No. 5/2006 about National Energy Policy (Anonim 2006) and the Presidential Instruction No. 1 of 2006 about Supply and Use of Bio-fuel as an alternative fuel (Anonym 2006). In order to support the government's policy regarding these fuels, it is necessary to develop and utilize the bio fuels considered the resources and opportunities that can be developed in a particular area or location.

A biodiesel plant in Kotabaru District at Province of South Kalimantan was an implementation activity of those regulations and it has been built since 2009 by partnership of Ministry of Research and Technology and Government of Kotabaru District in capacity of 6 tons/day (BRDST 2009). However, the biodiesel plant was not operated ever since the commissioning steps on 2009 due to some technical and non-technical problems. It was necessary to study of the revitalization of the biodiesel plant before in order to calculate technical and economic feasibility of re-operated biodiesel plant base on its capacity. In the future, revitalization could provide economic revenue to local government and communities in Kotabaru District and the biodiesel produced could substituted diesel fuel in that district.

\section{Material and Method}

The study was conducted during SeptemberNovember 2012 and involved:

a. Interviews and discussions with local government and local people near to the biodiesel plant.

b. On site survey for identification of existing problems base on current biodiesel condition.

c. Formulation of technical and non-technical problems and then calculation of repair cost.

d. Strength, Weakness, Opportunity and Treat (SWOT) analysis. SWOT analysis conducted by identification of SWOT factor, scoring of factors on scale of 1 up to 4, making a matrix of internal and external factor, calculating the score of each matrix and concluding the score and the proposed strategic management (David 2003).

e. Economic and sensitivity analysis (Coulson \& Richardson 1989) f. Providing recommendations and strategies which predicted the output and impact of this project to the owner.

Economic analysis was prepared to calculate the economic feasibility of 3 scenarios below:

a. Repairing the biodiesel plant at the current location, to conduct improvements or replacement all the equipment and re-commissioning operation in order to meet quality products of SNI 04-7182-2006 (Scenario 0).

b. Integrating biodiesel plants with palm oil mill, to set mutual business cooperation, and revitalize the plant in order to operate properly (Scenario 1).

c. Moving it closer to the biodiesel fuel users i.e. the coal mining industry located in the Kotabaru District, revitalize of all equipments to be able to reoperate, and utilize the product for mining operation units (Scenario 2).

Table 1 showed the differences of assumptions in 3 scenarios for the economic analysis. Based on the economic analysis, the influence factors to the production cost of biodiesel and the best scenario will be obtained. Then the sensitivity analysis of the best scenario was conducted (Coulson \& Richardson 1989).

Table 1

Some Sensitivity Factors in 3 Scenarios

\begin{tabular}{cccc}
\hline \multirow{2}{*}{ Scenario } & \multicolumn{3}{c}{ Sensitivity Factors } \\
\cline { 2 - 4 } & CPO Price & Methanol Price & Coal Price \\
\hline 0 & $100 \%$ & $100 \%$ & $100 \%$ \\
\hline 1 & $100 \%$ & $100 \%$ & $100 \%$ \\
\hline 3 & $70 \%$ & $100 \%$ & $-\%$ \\
\hline
\end{tabular}

The assumptions for the economic analysis as follows:

a. Price of Equipments and Materials.

The equipments and materials price obtained from vendor based on the quotation or price estimation.

b. Interest.

Interest was not taken into account because there is no credit mechanism in plant revitalization.

c. Tax

Taxes were not taken into account because the plant is managed by local government company (BUMD) that receive tax exemptions.

d. Current exchange

US dollar exchange rate : USD 1 was IDR 9.500,00.

e. Raw Material Price (as of September 2012)

Price of Raw Material presented at Table 1. 
Table 2

Assumptions of Raw Material Price

\begin{tabular}{lcc}
\multicolumn{1}{c}{ Description } & $\begin{array}{c}\text { Unit Price } \\
\text { (IDR/kg) }\end{array}$ & $\begin{array}{c}\text { Consumption } \\
\text { (Billion IDR/Year) }\end{array}$ \\
\hline $\mathrm{CPO}^{1}$ & 8.075 & 14.98 \\
\hline $\mathrm{Methanol}^{2}$ & 7.500 & 2.48 \\
\hline $\mathrm{NaOH}^{3}$ & 8.500 & 0.16 \\
\hline $\mathrm{H}_{2} \mathrm{SO}_{4}{ }^{3}$ & 7.500 & 0.43 \\
\hline $\mathrm{H}_{3} \mathrm{PO}_{4}{ }^{3}$ & 11.000 & 0.012 \\
\hline Bentonite $^{4}$ & 2.500 & 0.011 \\
\hline Water for process & 100 & 0.286 \\
\hline${ }^{1}$ Kemendag, 2012 & & \\
2Methanex, 2012 & & \\
3Sumber Kimia, 2012 & & \\
4Sud-chemie, 2012 & \\
5BRDST, 2012 & &
\end{tabular}

f. Product Selling Price (based on the HPE (Export Index Price) Biodiesel)

Selling price (price index of HPE) (Kemendag, 2012) on September 2012 was IDR 8.455,00/liter.

g. Production Capacity

Biodiesel production capacity was 6 tons/day (1800 tons / year). $1^{\text {st }}$ Year operates $50 \%$ and $2^{\text {nd }}$ year $75 \%$ of production capacity. Plant fully operational in $3^{\text {rd }}$ year.

h. Yield and Methanol Recovery.

Yield of the biodiesel production was $97 \% \mathrm{v} / \mathrm{v}$ and Methanol Recovery was $60 \% \mathrm{v} / \mathrm{v}$.

i. Lifetime of Equipment

Lifetime of equipment was 10 (ten) years.

j. Depreciation

Depreciation of equipment was accounted for 10 (ten) years or $10 \% /$ years.

k. Operating Time

Plant operating time was 2 shifts per day, 8 hours per shift and 25 days per month or 300 days per year.

l. Others

Byproduct i.e. glycerol was excluded.

\section{Result and Discussion}

\subsection{Technical Analysis}

Background for this project are to develop a technology to initiate the local goverment to process the citizen's palm oil directly, in order to reduce the cost for delivery, subtitute the local diesel fuel consumption with alternative energy base on local resources. It is also to endorse the local cooperation to produce biodiesel from raw material resources, independently.
Base on identification, there are $75 \%$ equipments still in good condition, $15 \%$ need to repair even $10 \%$ need to be replaced. The biodiesel plant was not operated because:

1. Most of the equipments were damaged because they had been in idle condition for more than 3 years after commissioning step. Some moving equipments and instruments did not work properly. Base on calculation, it was found that loss of investment approximately $25 \%$, about 1,8 Million. It was assumed that depreciation for 10 (ten) years.

2. It did not have security supply of Crude Palm Oil (CPO) from a certain supplier at certain price and specific amount. The local government planned to build palm oil mill as off taker of the palm fruit from smallholder plantation at that area and to supply CPO to the biodiesel plant. However, the plan was canceled for unknown reason. Other possible feedstock (Crude Jatropha Oil) could not be supplied because it was not available in Kotabaru District.

3. Utility system especially electricity supply from PLN (State owned power company) was not connected while the current electricity source was from generator. So that the operating costs became higher because it required large amount of fuel (300 liters/day) that will affect to the production cost of biodiesel. In addition, water supply for boiler, cooling tower and process was obtained from outside of the plant and the cost of this water becomes greater when compared with its own supply of groundwater. High utility costs contributed to high biodiesel production costs.

4. Operation of biodiesel plant needs to be supported by workshop facilities for maintenance. Lack of workshop facilities in the plant can lead to a longer time to repair and maintenance. So that the biodiesel plant required a good amount of spare parts/equipment to maintain the production schedule where damage occurred.

5. The owner of the plant had not established manager and operators of the plant.

6. There was a market competition with subsidized diesel fuel price. Market will prefer to use subsidized diesel fuel as long as the biodiesel price was higher than diesel fuel price.

After finding these issues, the cost to revitalize biodiesel plant 6 ton / day in Kotabaru was analyzed. The result was that the project required around 1.4 billion rupiahs for repair, replacement and installation 
all the equipment in order to re-operate the biodiesel plant.

\subsection{SWOT Analysis}

SWOT analysis was performed as strategic management assessment to see which factors that influenced the revitalization of biodiesel plant. Strengths and weaknesses were defined as internal factors, while opportunities and threats were the external factors. The identification of each factor was presented at Table 3 and Table 4.

Internal and external factors' matrix was arranged based on the level of influence of the factors that determined the revitalization process. The result on the internal factor was 3.22 (Table 3), which means the plant was in the range of "growth and build". The biodiesel plant has a potential to grow and produce the economic benefits (David, 2003). The potential growth and build plants gave an information to all stakeholders to strive for intensive revitalization of the biodiesel plant and gave attention to the integration of the security supply of raw materials with a clear biodiesel market. The development of this plant depends on the efforts of market development and penetration, product innovation and byproducts processing, and supports from the local government.

Table 3

Strength and Weakness Matrix (Internal Factor Evaluation)

\begin{tabular}{lccc}
\hline Strength & Weight & Rank & Score \\
\hline $\begin{array}{l}\text { biodiesel plant was commissioning } \\
\text { and proved to operate well. }\end{array}$ & 0.1 & 4 & 0.4 \\
\hline $\begin{array}{l}\text { supporting infrastructure i.e, } \\
\text { laboratories and security posts had } \\
\text { been prepared. }\end{array}$ & 0.04 & 3 & 0.12 \\
\hline $\begin{array}{l}\text { biodiesel products meet ISO } \\
\text { standards and can be used directly } \\
\text { in diesel engine/boiler/generator }\end{array}$ & 0.06 & 3 & 0.18 \\
\hline $\begin{array}{l}\text { Biodiesel was able to meet the } \\
\text { needs of biodiesel in Kotabaru } \\
\text { about 6 tons/day }\end{array}$ & 0.1 & 3 & 0.3 \\
\hline $\begin{array}{l}\text { Biodiesel was environmental } \\
\text { friendly }\end{array}$ & 0.05 & 3 & 0.15 \\
\hline $\begin{array}{l}\text { Created new jobs opportunities } \\
\text { Source of revenue for the local } \\
\text { government and local society. }\end{array}$ & 0.05 & 3 & 0.15 \\
\hline $\begin{array}{l}\text { Utilization of the local resources } \\
\text { (Kotabaru District). }\end{array}$ & 0.02 & 2 & 0.04 \\
\hline
\end{tabular}

\begin{tabular}{lccc}
\hline Weakness & Weight & Rank & Score \\
$\begin{array}{l}\text { The availability of clean water } \\
\text { around the site were not secure. }\end{array}$ & 0.03 & 3 & 0.09 \\
\hline $\begin{array}{l}\text { A lots of equipment and control } \\
\text { systems were damaged. }\end{array}$ & 0.1 & 4 & 0.4 \\
\hline $\begin{array}{l}\text { There was no written partnership } \\
\text { letter of contract) in terms of } \\
\text { marketing the product. }\end{array}$ & 0.11 & 3 & 0.33 \\
\hline $\begin{array}{l}\text { Raw materials (CP0) were not yet } \\
\text { available. }\end{array}$ & 0.14 & 4 & 0.56 \\
\hline $\begin{array}{l}\text { There were no } \\
\text { wokshop/maintenance facilities }\end{array}$ & 0.03 & 3 & 0.09 \\
\hline $\begin{array}{l}\text { The operators were no experience } \\
\text { in operating the plant }\end{array}$ & 0.02 & 3 & 0.06 \\
\hline $\begin{array}{l}\text { There was no Waste Treatment } \\
\text { Plant }\end{array}$ & 0.03 & 1 & 0.03 \\
\hline $\begin{array}{l}\text { Did not have a chemical } \\
\text { warehouse }\end{array}$ & 0.02 & 1 & 0.02 \\
\hline Total & 1 & & 3.22 \\
\hline
\end{tabular}

The result on the external factor was 3.04 (Table 4). It showed smaller score compared to the internal factors. This means that the internal factors gave a greater influence on revitalization than external factors. Hence, the success of revitalization efforts are more influenced by the ability of local governments and society to manage the biodiesel plant using all of existing resources in Kotabaru District. However the external support is also needed. 
Table 4

Opportunity and Treats Matrix (External Factor Evaluation)

\begin{tabular}{llcc}
\hline Opportunity & Weight & Rank & Score \\
\hline $\begin{array}{l}\text { Local government policy in order } \\
\text { to run a profitable this biodiesel } \\
\text { plant }\end{array}$ & 0.12 & 4 & 0.48 \\
\hline $\begin{array}{l}\text { The largest plantation } \\
\text { commodities in Kotabaru district is } \\
\text { palm oil. }\end{array}$ & 0.1 & 4 & 0.4 \\
\hline $\begin{array}{l}\text { Some palm oil mill owned by } \\
\text { private company neraby the } \\
\text { biodiesel plant, an opportunity to } \\
\text { make a mutual partnership. }\end{array}$ & 0.09 & 3 & 0.27 \\
\hline $\begin{array}{l}\text { MP } \text { EI mandates of Kalimantan } \\
\text { Economic Corridor as a national } \\
\text { energy resources }\end{array}$ & 0.08 & 3 & 0.24 \\
\hline $\begin{array}{l}\text { Domestic investment } \\
\text { opportunities }\end{array}$ & 0.06 & 2 & 0.12 \\
\hline $\begin{array}{l}\text { Opportunities to create green and } \\
\text { environmental friendly energy. }\end{array}$ & 0.06 & 2 & 0.12 \\
\hline Treat & & & \\
\hline $\begin{array}{l}\text { PLN could not supply the } \\
\text { electricity needs of the plant due to } \\
\text { the limited power source. }\end{array}$ & 0.12 & 3 & 0.36 \\
\hline $\begin{array}{l}\text { Security of supply of raw materials } \\
\text { and chemicals is uncertained. }\end{array}$ & 0.12 & 4 & 0.48 \\
\hline $\begin{array}{l}\text { Access road to the site is still } \\
\text { damaged }\end{array}$ & 0.11 & 3 & 0.33 \\
\hline $\begin{array}{l}\text { Pricing policies do not support the } \\
\text { development of biodiesel }\end{array}$ & 0.05 & 2 & 0.1 \\
\hline $\begin{array}{l}\text { Government is less consistent in } \\
\text { developing biodiesel industry }\end{array}$ & 0.07 & 2 & 0.14 \\
\hline \begin{tabular}{l} 
Total \\
\hline
\end{tabular} & 0.98 & 32 & 3.04 \\
\hline
\end{tabular}

\subsection{Economic Analysis}

Based on the results of the economic calculation on scenario 0 , which means plant operated in the existing location, it was concluded that this scenario was not profitable (table 5). Production cost of Scenario 0 was about IDR 11,65 million/ton when the biodiesel price of IDR. 8.455,-/liter or IDR. 7,27 million/ton and in operation it would be loss about Rp. 5.744,6 Milion/year (table 6). It caused of the loss as follows:

a. Supply of water was not secure due to unavailable source of clean water during the year that required for process and cooling tower $\left(10 \mathrm{~m}^{3} /\right.$ day $)$.

b. Electricity supply from PLN (State owned power company) was not connected while the current electricity source was from generator.

c. Steam was generated using coal fired boiler while the supply of coal ( 2 tons/day) was not secure. The coal prices would increase the production costs. d. Waste water treatment plant in the biodiesel plant was not yet available while the waste water produced from washing step was about 9 tons/day. This condition would be a problem if the plant has been operating in the current location.

e. It required distribution cost for delivery to consumer.

On scenario 1, the plant was relocated to a nearby palm oil mill (integrated with palm oil mill). In scenario 1, production cost IDR 8,07 million/ton after third year (table 5). The owner would get revenue in one year about IDR 687,68 Million/year (table 6). Results of economic analysis suggested that this scenario could be feasible and be profitable, although on the first year and second year the income was still small. Plant was assumed to operate at $50 \%$ of capacity on the first year, while at $75 \%$ capacity on the second year. For the third year, the plant was operated normally and generating profits for owner.

Table 5

Production Cost/ton (Million Rp)

\begin{tabular}{cccc}
\hline Years & Scenario 0 & Scenario 1 & Scenario 2 \\
\hline 1 & 12,16 & 8,58 & 11,18 \\
\hline 2 & 11,82 & 8,24 & 10,97 \\
\hline 3 & 11,65 & 8,07 & 10,87 \\
\hline 4 & 11,65 & 8,07 & 10,87 \\
\hline 5 & 11,65 & 8,07 & 10,87 \\
\hline 6 & 11,65 & 8,07 & 10,87 \\
\hline 7 & 11,65 & 8,07 & 10,87 \\
\hline 8 & 11,65 & 8,07 & 10,87 \\
\hline 9 & 11,65 & 8,07 & 10,87 \\
\hline 10 & 11,65 & 8,07 & 10,87
\end{tabular}

Based on the result of the survey, there are several palm oil mill that owned by private company that willing to with the local governments. In this scenario, as an owner, the local government could make a mutual partnership with the palm oil mill owner. This scenario would integrate the biodiesel plant with palm oil mill, so that the CPO supply would be secured and biodiesel could be consumed by transportation unit in the both of plant oil mill and biodiesel plant. This scenario would reduce production cost on palm oil mill by substitution of industrial diesel oil (app. IDR 11.000,-/liter) with biodiesel fuel. 
Scenario 2 was an approach to locate biodiesel production facilities to biodiesel consumer i.e. mining transportation unit activities. By relocating the plant to mining area, the cost coal will be lower. However, as in Scenario 0 , this scenario was not able to supply CPO by its own and required transport costs in the procurement of feedstocks. So that the biodiesel plant would loss IDR 4.347,68 Million/year after it operated in full capacity. The production cost was lower than scenario 0 but it was higher than scenario 1 .

Table 6

Margin/year (Million IDR)

\begin{tabular}{cccc}
\hline Years & Scenario 0 & Scenario 1 & Scenario 2 \\
\hline 1 & $-3.331,53$ & $-115,37$ & -2.453 .04 \\
\hline 2 & $-4.538,09$ & 286,16 & -3.400 .36 \\
\hline 4 & $-5.744,64$ & 687,68 & -4.347 .68 \\
\hline 5 & $-5.744,64$ & 687,68 & $-4.347,68$ \\
\hline 6 & $-5.744,64$ & 687,68 & $-4.347,68$ \\
\hline 7 & $-5.744,64$ & 687,68 & $-4.347,68$ \\
\hline 8 & $-5.744,64$ & 687,68 & $-4.347,68$ \\
\hline 9 & $-5.744,64$ & 687,68 & $-4.347,68$ \\
\hline 9 & $-5.744,64$ & 687,68 & $-4.347,68$ \\
\hline 10 & $-5.744,64$ & 687,68 & $-4.347,68$ \\
\hline
\end{tabular}

\subsection{Sensitivity Analysis}

Based on the factors that determined the production cost, then the sensitivity of the price of some components in production costs by changing the amount of these factors was conducted. It was concluded that the sensitivity of profit or loss was highly influenced by biodiesel price.

The result of the sensitivity analysis was presented at Table 7. On the analysis, there were 4 factors that varied and then the effect of those variabels to the production cost and margin or revenue was calculated.

Table 7 showed that the most sensitive factor that can reduce the financial margin was the increasing of $\mathrm{CPO}$ price (Scenario 1A). However, methanol price also gave influence to the financial margin even though not as much as CPO price. Furthermore, it can be concluded that despite the increasing of CPO Price, labor cost, methanol price on $10 \%$ respectively, the integration biodiesel plant to palm oil mill would gain positive margin if the biodiesel price increased $5 \%$. Base on industrial diesel oil price (app. IDR 11.000,-), scenario 1 would be a profitable biodiesel plant eventhough CPO, methanol and labour cost increased $10 \%$ respectively.

Table 7

Margin/ton in some sensitivities of scenario (IDR)

\begin{tabular}{|c|c|c|c|c|c|}
\hline \multirow{2}{*}{ Scenario } & \multicolumn{4}{|c|}{ Sensitivity } & \multirow{2}{*}{$\begin{array}{c}\text { Margin } \\
\text { (IDR/ton) }\end{array}$} \\
\hline & $\begin{array}{c}\text { CPO } \\
\text { Priced }\end{array}$ & $\begin{array}{c}\text { Labour } \\
\text { Cost }\end{array}$ & $\begin{array}{c}\text { Methanol } \\
\text { Price }\end{array}$ & $\begin{array}{c}\text { Biodiesel } \\
\text { Price }\end{array}$ & \\
\hline 1 & - & - & - & - & 382,045 \\
\hline $1 \mathrm{~A}$ & $+10 \%$ & - & - & - & $-200,687$ \\
\hline $1 \mathrm{~B}$ & $+10 \%$ & $+10 \%$ & & & $-213,487$ \\
\hline $1 \mathrm{C}$ & $+10 \%$ & $+10 \%$ & $+10 \%$ & & $-351,652$ \\
\hline 1D & $+10 \%$ & $+10 \%$ & $+10 \%$ & $+5 \%$ & 77,498 \\
\hline
\end{tabular}

Relocation biodiesel plant to palm oil plant in order to ensure the supply of raw materials CPO, utility supply and support of other facilities owned by the palm oil mill for the production of biodiesel was the best choice. Results of SWOT analysis and economic feasibility analysis recommended that the biodiesel plant's relocation to the palm oil mill will provide technical and economic benefits to the sustainability of the biodiesel plant operation. Repair and re-commissioning and operator training can be done after the plant installed at palm oil mills. The local government must create the mutual benefit scenario of cooperation with the private company managed the palm oil mill.

To ensure the use and utilization of biodiesel produced, biodiesel produced by the biodiesel plant can be used for operational purposes of palm oil mills, plantation units, and can be sold to the other industries such as coal mining industries in order to substitute diesel fuel for transportation and electric generators.

\section{Conclusion}

Base on the study, it can be concluded that the biodiesel plant with 6 tpd capacity in Kotabaru could not be operated because of technical, management and economic problems. Based on the SWOT Analysis, it was found that the operation of biodiesel plant was strongly influenced by the security of supply and price of raw material, local government efforts to penetrate the market, and increased added-value of by-product. Economic calculation analysis results that integrating biodiesel plant with palm oil mill nearby was the best option (Scenario 1). Based on sensitivity analysis of 
Scenario 1, financial margin was strongly influenced by the CPO, methanol and biodiesel prices.

\section{Acknowledgements}

The authors would like to thank all the authors who have worked doing this study together and thanks also to the ministry of research and technology for the research funding on Science and Technology Capacity Building for Economic Corridor Grant 2012.

\section{References}

Briggs. M. (2008), Biodiesel production - current state of the art and challenges, Journal of Industrial Microbiology Biotechnology 35, 421-430.

BRDST (2009) Laporan Akhir Komisioning Biodiesel Plant Cap. 6 tons/day, Kotabaru, South Kalimantan.

BRDST (2012) Laporan Kajian Revitalisasi Pabrik Biodiesel Kapasitas 6 Ton.hari, Kotabaru, South Kalimantan.

David, F.R. (2002) Strategic Management: Concept (in Indonesian), Jakarta; Pearson Education Asia Pte. Ltd and Prenhalindo.

David, F.R. (2003) Strategic Management: Concept and Cases, $10^{\text {th }}$ ed., Prentice Hall International.

Enguidanos M., Soria A., Kavalov B. \& Jensen P. (2002) Technoeconomic analysis of biodiesel production in the EU. Institute for Prospective Technological Studies.

Government of Indonesia (2006) Presidential Instruction No. 1 Tahun 2006 about Supply and Utilization Biofuel as alternative fuel, Jakarta ; www.esdm.go.id accessed at Mei 2013.

Government of Indonesia (2006) Presidential Decree No.5 Tahun 2006 on National Energy Policy, Jakarta ; www.esdm.go.id, accessed at Mei 2013.

Haas, M.J., McAloon,, M.J. Yee, W.C. \& Foglia, T.A. (2005) A process model to estimate biodiesel production costs, Journal of Bioresources Technology 97, 671-678.

Methanex (2012), Methanex methanol price sheet, September 2012, accessed at 29 September 2013.

Minister of Trade (2012), Trade Ministrial Regulation No. 62 about Export Price Index on agricultural and forestry products are subjected by export cost, Jakarta.

Sud-Chemie (2012), Bentonite quotation letter (Februari 2012), Bogor. Tjakrawan, P. (2012) Kesiapan Pasokan Bahan Bakar Nabati/Biodiesel, Jakarta ; Sosialisasi Teknik Pencampuran BBN Dengan BBM.

Toko Alam Kimia (2012), Quotation letter (Januari 2012), Jakarta. 